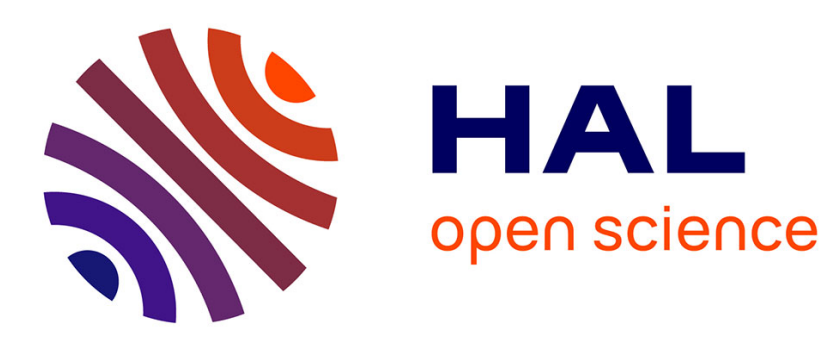

\title{
The Z-score is dead, long live the Z-score! A new way to measure bank risk
}

Ion Lapteacru

\section{To cite this version:}

Ion Lapteacru. The Z-score is dead, long live the Z-score! A new way to measure bank risk. 2017. hal-01518652

\section{HAL Id: hal-01518652 \\ https://hal.science/hal-01518652}

Preprint submitted on 5 May 2017

HAL is a multi-disciplinary open access archive for the deposit and dissemination of scientific research documents, whether they are published or not. The documents may come from teaching and research institutions in France or abroad, or from public or private research centers.
L'archive ouverte pluridisciplinaire $\mathbf{H A L}$, est destinée au dépôt et à la diffusion de documents scientifiques de niveau recherche, publiés ou non, émanant des établissements d'enseignement et de recherche français ou étrangers, des laboratoires publics ou privés. 



\section{AUTHORS}

Ion Lapteacru, Larefi, Université de Bordeaux

\section{NOTICES}

LAREFI Working Papers contain preliminary material and research results. They have been peer reviewed. They are circulated in order to stimulate discussion and critical comment; any opinions expressed are only those of the author(s).

Copyright LAREFI. All rights reserved. Sections of this material may be reproduced for personal and not-forprofit use without the express written permission of but with acknowledgment to LAREFI. To reproduce the material contained herein for profit or commercial use requires express written permission. To obtain permission, contact LAREFI at cyril.mesmer@u-bordeaux.fr. 


\begin{abstract}
This paper raises questions about the consistency of the Z-score, which is the most applied accounting-based measure of bank risk. In spite of its main advantage, namely the concept of risk on which it relies, the traditional formula is precisely inconsistent with this concept. The Z-score is deduced from the probability that bank's losses exceed its capital, but under the very unrealistic assumption of normally distributed returns on assets. Consequently, we propose a structural approach to determine this bank risk measure. It consists to define the default event when banks' profit is lower than a default threshold level, which is based on the balance-sheet structure of banks and on new prudential regulation requirements.
\end{abstract}

\title{
JEL classification: G21
}

Keywords: Z-score; Bank risk; Banking. 


\section{Introduction}

A major challenge in the empirical banking literature is to conceive accurate measures of bank risk based on accounting data. This issue is of a particular importance and interest, because many banks are not listed, especially in emerging and developing countries, and there is no really a consistent accounting-based measure to gauge their risk. The most used and conceptually very interesting measure is the Z-score, but it undergoes many important shortcomings. Computed as the ratio of a bank's leverage (capital on assets) and the mean of its returns on assets ratio, $R O A$, on the volatility of this ratio, this risk measure was conceived from the concept of a bank's default probability (Hannan and Hanweck, 1988; Boyd and Runkle, 1993; Boyd et al., 1993).

However, this latter feature is a misinterpretation of the Z-score, because it can reflect the inverse probability of insolvency of a bank only if the returns on assets, as a random variable, are normally distributed. The main strength of the Z-score lies in its foundation of the risk concept, which completely vanishes if the normal distribution assumption is not respected. Moreover, the default definition is also very binding since banks can go bankrupt with losses lower than the level of their capital, even with small profits.

In this paper, we propose a fundamentally very different concept of the Z-score based on the balance-sheet structure of banks. The next section mentions the principal shortcomings of the traditional Z-score. Section 3 presents our structural approach of this accounting-based risk measure, and Section 4 concludes.

\section{Inconsistency of the traditional Z-score}

The traditional approach to compute this accounting-based bank risk measure is

$Z_{\text {trad }}=\frac{C A R+E(R O A)}{\sigma(R O A)}$

where $R O A$ and $C A R$ are returns on assets and capital on assets ratios, respectively, and the former is also a random variable, which precisely participates to define the default event and to compute the probability of default. $E(R O A)$ is the expected value of $R O A$ and $\sigma(R O A)$ its standard deviation. A bank defaults when its current losses exceed its capital and the probability of default is, in consequence, $\operatorname{Pr}[-\Pi>C]$, where $\Pi$ and $C$ are its profit and capital, respectively. Normalising by the bank's size, expressed by its assets' level $A$, the probability of default becomes $\operatorname{Pr}[R O A \leq-C A R]$. Within the traditional approach, according to Boyd and Runkle, (1993), Hannan and Hanweck (1988), and Boyd et al. (1993), one assumes that $R O A$ is normally distributed and the probability of default is therefore given by

$\operatorname{Pr}[R O A \leq-C A R]=\operatorname{Pr}\left[\frac{R O A-E(R O A)}{\sigma(R O A)} \leq-\frac{C A R+E(R O A)}{\sigma(R O A)}\right]=N(-Z)=1-N(Z)$

where $N($.$) is the normal cumulative distribution function.$

The assumption of normally distributed $R O A$ allows the derivation of a simple but inconsistent formula for the Z-score. Indeed, the distribution of the $R O A$ is asymmetric (skewed) and has an excess of kurtosis. According to Boyd and Runkle (1993), Hannan and Hanweck (1988), and Boyd et al. (1993), even if the $R O A$ is not normally distributed, using the Bienaymé-Tchebycheff inequality, the Z-score remains still a good measure of bank risk and becomes the inverse measure of the upper bound of the default probability: 
$\operatorname{Pr}[R O A \leq-C A R]=\operatorname{Pr}[R O A-E(R O A) \leq-(C A R+E(R O A))] \leq \frac{\sigma^{2}(R O A)}{2(C A R+E(R O A))^{2}}=\frac{1}{2 Z^{2}}$

Nevertheless, the upper bound of the default probability provides no information about its true value, or at least its expected value. For this reason, the Z-score, without the normal distribution assumption, cannot ensure the comparability of bank risk data.

The traditional formula of the Z-score (eq. 1) has been applied in very different ways. Some authors computed empirical mean and standard deviation of the $R O A$ random variable on the whole period sample (Demirgüç-Kunt and Huizinga, 2010), others estimate $E(R O A)$ and $\sigma(R O A)$ only on a part of the time sample (2, 3, 4 or 5 years) and roll these calculus on this time window on the rest of the sample (Anginer et al., 2014; Williams, 2014; among others). Many papers in banking literature treat the risk of banks using a Z-score with ROA in level instead of average in the numerator (Lee and Hsieh, 2014; Chortareas et al., 2012; Niu, 2012), suppressing thus the random feature of the $R O A$ variable, which is at the heart of the concept of this bank risk measure. The probability of default, $\operatorname{Pr}[R O A \leq-C A R]$, has no more sense since it does no longer participate to the determination of the Z-score formula.

All these computation methods either neglect the default concept behind the Z-score or do not free this measure from the unrealistic constraint of normal distribution for the $R O A$ variable. Laeven and Levine (2009) and Demirgüç-Kunt et al. (2008), for instance, propose to use the natural logarithm of the Z-score and that of one plus Z-score, respectively. However, Lapteacru (2016) shows that the logarithmic transformation does not mitigate the skewness of $R O A$ distributions. He also proposes new statistical adjustments that consist to estimate the real distribution of the $R O A$ variable in order to apply the default probability formula instead of the traditional Z-score. The author applies the skew normal and stable distributions that both deal with the skewness of $R O A$ data. However, the original and traditional concept of the Z-score does not consider the structure of banks' balance-sheet and defines the default event as an extreme case because current losses can be lower than the capital of an insolvent banking institution. For example, many Central and Eastern European banks had a profit when defaulting.

\section{A new Z-score measure: a structural approach}

In this section we propose a structural version of the most applied accounting-based bank risk measure. Let us suppose that a bank's profit $\Pi_{t}$ follows the geometric Brownian motion

$\frac{d \Pi_{t}}{\Pi_{t}}=\mu_{\Pi} d t+\sigma_{\Pi} d W_{t}$

where $\mu_{\Pi}$ and $\sigma_{\Pi}$ are the expected return and return volatility of the bank's profit, respectively, and $W_{t}$ is a Wiener process, $d W_{t} \sim N(0, d t)$. The solution of this stochastic differential equation is $\Pi_{T}=\Pi_{t} e^{\left(\mu_{\Pi}-0.5 \sigma_{\Pi}^{2}\right)(T-t)+\sigma_{\Pi} \sqrt{T-t} U_{t}}$, where $U_{t} \sim N(0,1)$. For examining whether the bank does not default next year, we consider the following form of the profit evolution:

$$
\Pi_{t+1}=\Pi_{t} e^{\left(\mu_{\Pi}-0.5 \sigma_{\Pi}^{2}\right)+\sigma_{\Pi} U_{t}}
$$

The next year, if the profit of the bank is lower than a default threshold $\Pi_{d, t+1}$, then the bank goes bankrupt. Thus, according to the default event, $\Pi_{t+1} \leq \Pi_{d, t+1}$ and 
$U_{t} \leq-\frac{\operatorname{Ln}\left(\Pi_{t} / \Pi_{d, t+1}\right)+\left(\mu_{\Pi}-0.5 \sigma_{\Pi}^{2}\right)}{\sigma_{\Pi}}$

Therefore, the probability of default is given by

$$
P_{d, t}=\operatorname{Pr}\left(\Pi_{t+1} \leq \Pi_{d, t+1}\right)=\operatorname{Pr}\left(U_{t} \leq-\frac{\operatorname{Ln}\left(\Pi_{t} / \Pi_{d, t+1}\right)+\left(\mu_{\Pi}-0.5 \sigma_{\Pi}^{2}\right)}{\sigma_{\Pi}}\right)=N\left(-Z_{t}\right) .
$$

In contrast with eq. (2), the main advantages of our structural Z-score,

$Z_{\text {struct }, t}=\frac{\operatorname{Ln}\left(\Pi_{t} / \Pi_{d, t+1}\right)+\left(\mu_{\Pi}-0.5 \sigma_{\Pi}^{2}\right)}{\sigma_{\Pi}}$

are as follows. First, it is based on a different event of default: the bank goes bankrupt if its profit is lower than a default threshold instead than $-C$ which is a very seldom case. Second, the random feature of the profit variable is explicitly considered through the Brownian geometric motion. Finally, the default threshold level of profits is based on the leverage principle required by the Basel 3 regulation and on the balance-sheet structure of the bank.

According to the new prudential regulation, a bank is considered insolvent if its leverage ratio is lower that the leverage limit ${ }^{1}$ :

$\frac{K_{t+1}}{D_{t+1}+K_{t+1}} \leq$ Leverage,

where $K$ and $D$ are, respectively, the bank's capital and debt. Let us consider the extreme case when the bank retains all its profit into its capital, that is $K_{t+1}=K_{t}+\Pi_{t+1}$. The previous leverage constraint is then transformed into default constraint for profits:

$\Pi_{t+1} \leq D_{t+1} \frac{\text { Leverage }}{1-\text { Leverage }}-K_{t}$

From our defined default event, that is $\Pi_{t+1} \leq \Pi_{d, t+1}$, we obtain

$\Pi_{d, t+1}=\bar{D}_{t+1} \frac{\text { Leverage }}{1-\text { Leverage }}-K_{t}$

where $\bar{D}_{t+1}$ is the expected value of the bank's debt in $t+1$. The expected value is computed for values of the bank's debt ranging from $D_{t}-\sigma_{D, t}$ to $D_{t}+\sigma_{D, t}$, where $\sigma_{D, t}$ is the standard deviation of the debt distribution:

$\bar{D}_{t+1}=\mathrm{E}\left(D_{t+1} \mid D_{t}-\sigma_{D, t} \leq D_{t+1} \leq D_{t}+\sigma_{D, t}\right)=\frac{\int_{D_{t}-\sigma_{D, t}}^{D_{t}+\sigma_{D, t}} d F_{D}(x)}{F_{D}\left(D_{t}+\sigma_{D, t}\right)-F_{D}\left(D_{t}-\sigma_{D, t}\right)}$

The cumulative distribution function of the debt, $F_{D}(x)$, is obtained with the skew normal distribution, which allows the consideration of the skewness with the Owen (1956) function

\footnotetext{
${ }^{1}$ Leverage $=0.03$ within Basel 3 requirements (BIS, 2014).
} 
$T(x ; \mu, \sigma, \alpha)=\frac{1}{2 \pi} \int_{0}^{\alpha} \frac{\exp \left[-\frac{1}{2}\left(\frac{x-\mu}{\sigma}\right)^{2}\left(1+t^{2}\right)\right]}{1+t^{2}} d t$

Consequently, the cumulative distribution function is

$F_{\mathrm{SkND}}(x ; \mu, \sigma, \alpha)=N(x ; \mu, \sigma)-2 \mathrm{~T}(x ; \mu, \sigma, \alpha)$,

where $\alpha$ is the skewness parameter. For $\alpha=0, F_{\text {SkND }}(x ; \mu, \sigma, 0)=N(x ; \mu, \sigma)$ and the distribution is symmetric. Otherwise, if $\alpha<0$, then $T(x ; \mu, \sigma, \alpha)<0$ and $F_{\text {SkND }}(x ; \mu, \sigma, \alpha)>$ $N(x ; \mu, \sigma)$, and the distribution is left-skewed. For $\alpha>0$, we obtain $T(x ; \mu, \sigma, \alpha)>0$, $F_{\text {SkND }}(x ; \mu, \sigma, \alpha)<N(x ; \mu, \sigma)$ and a right-skewed distribution.

To determine the parameters $\mu, \sigma$ and $\alpha$ we follow Lapteacru (2016) and apply the distance minimisation algorithm. The parameters are estimated to minimise the distance between the skew normal probability density function and that of the smooth kernel distribution given by a linearly interpolated version of $\frac{1}{n h} \sum_{i=1}^{n} k\left(\frac{x-x_{i}}{h}\right) \cdot k(x)$ is the smoothing kernel, $h$ the bandwidth parameter and $n$ the number of observations of the sample consisting of $x_{i}$ values. The distribution parameters are estimated only for banks with a chosen minimum number of observations and are also used to compute $\sigma_{D, t}, \sigma_{D, t}=\sigma_{t} \sqrt{1-\frac{2 \alpha^{2}}{\pi\left(1+\alpha^{2}\right)}}$. To keep the coherence of the estimation approach, the same procedure can be applied in the determination of the expected return, $\mu_{\Pi}$, and the return volatility, $\sigma_{\Pi}$, of the bank's profit, but with normal distribution of the $\Delta \Pi_{t} / \Pi_{t-1}$ variable.

\section{Conclusion}

This study firstly shows the inconsistency of the traditional Z-score and then proposes another approach to measure bank risk with banks' accounting data. The main advantages of our structural approach are the consideration of a more realistic default event, the modelling of the evolution path of the random variable, and, which is the most important, the determination of the default threshold level of profits from the balance-sheet structure of banks and from new prudential regulation requirements.

\section{Acknowledgements}

We wish to thank Pierre-Henri Faure for his constructive comments and helpful suggestions, which greatly contributed to improving this study. We also acknowledge support from the University of Bordeaux under Department of Social and Human Sciences (Grant no. BQR 2016). All remaining errors are own. 


\section{References}

Anginer, D., Demirgüç-Kunt, A., Zhu, M., 2014. How does deposit insurance affect bank risk? Evidence from the recent Crisis. Journal of Banking and Finance 48, 312-321.

BIS, Bank of International Settlements, 2014. Basel III leverage ratio framework and disclosure requirements.

Boyd, J.H., Runkle, D.E., 1993. Size and performance of banking firms. Journal of Monetary Economics 31, 47-67.

Boyd, J.H., Graham, S.L., Hewitt, S.R., 1993. Bank holding company mergers with nonbank financial firms: effects on the risk of failure. Journal of Banking and Finance 17, 43-63.

Chortareasa, G.E., Girardoneb, C., Ventouric, A., 2012. Bank supervision, regulation, and efficiency: Evidence from the European Union. Journal of Financial Stability 8, 292-302.

Demirgüç-Kunt, A., Detragiache, E., Tressel, T., 2008. Banking on the principles: Compliance with Basel Core Principles and bank soundness. Journal of Financial Intermediation 17, 511-542.

Demirgüç-Kunt, A., Huizinga, H., 2010. Bank activity and funding strategies: The impact on risk and returns. Journal of Financial Economics 98, 626-650.

Hannan, T.H., Hanweck, G.A., 1988. Bank insolvency risk and the market for large certificates of deposit. Journal of Money, Credit and Banking 20, 203-211.

Laeven, L., Levine, R., 2009. Bank governance, regulation and risk taking. Journal of Financial Economics 93, 259-275.

Lapteacru, I., 2016. On the consistency of the Z-score to measure the bank risk. LAREFI Working Paper n²016-05, University of Bordeaux.

Lee, C.-C., Hsieh, M.-F., 2014. Bank reforms, foreign ownership, and financial stability. Journal of International Money and Finance 40, 204-224.

Niu, J., 2012. An empirical analysis of the relation between bank charter value and risk taking. The Quarterly Review of Economics and Finance 52, 298-304.

Williams, B., 2014. Bank risk and national governance in Asia. Journal of Banking and Finance 49, 10-26. 


\section{RECENT LAREFI WORKINg PAPERS}

\section{For earlier LAREFI Working Papers, please go to http://lare-efi.u-bordeaux4.fr}

\section{All Discussion Papers can be downloaded free of charge}

CR16-EFI09 Lapteacru, I., "Bank Risk in Central and Eastern European Countries : Does Ownership Matter ?"

CR16-EFI08 Lapteacru, I., "Murphy-Topel adjustment of the variance-covariance matrix of a two-step panel data model : Evidence from competition-fragility nexus in banking"

CR16-EFI07 Faure, P-H., "Le bitcoin peut-il être assimilé à une monnaie ? Un examen à partir des différentes grilles de lecture de la science économique"

CR16-EFI06 Lapteacru, I., "Convergence of bank competition in Central and Eastern European countries : Does ownership matter ?"

CR16-EFI05 Lapteacru, I., "On the consistency of the Z-score to measure the bank risk"

CR16-EFI04 Lapteacru, I., "Income and funding structures, banking regulation and bank risk-taking : The role of ownership in Central and Eastern European banks"

CR16-EFI03 Humblot, T., "Distance et accès au crédit sous Bâle III"

CR16-EFI02 Berthoumieu, J. and V. Lamani, "Vertical Differentiation, Uncertainty, Product R\&D and Policy Instruments in a North-South Duopoly"

CR16-EFI01 Raffestin, L., "Foreign exchange investment rules and endogenous currency crashes"

CR15-EFI05 Berthoumieu,J., "Technology Diffusion via Patent Collaborations : The Case of European Integration"

CR15-EFI04 Bouet, A. and A-G. Vaubourg, "Financial Constraints and International Trade with Endogenous Mode of Competition"

CR15-EFI03 Lahet, D. and A-G. Vaubourg, "Banks' shareholding in multilateral trading facilities : A two-sided market perspective"

CR15-EFI02 Berthoumieu, J., "Policy Instruments, Patents and International Technology Diffusion in a North-South Duopoly"

CR15-EFI01 Dupuy, L., "International trade and structural change : a dynamic model of weak sustainability" 